\section{Journal of Sciences and \\ Engineering}

Vol. 4, $\mathbf{N}^{\circ} 1,2020$

\title{
Integration of women in agriculture in Cañete - Peru [Integración de la mujer en la agricultura en Cañete, Perú]
}

\author{
Bessy Castillo Santa Maríaa, Bertha Nancy Larico Quispe ${ }^{a}$, Rubén Andrés \\ Moreno Sotomayor ${ }^{\mathrm{b}}$ \\ aUniversidad Nacional de Cañete - Perú \\ bIESTP Cañete - Perú
}

bsscstll@gmail.com

Received: 27 January 2020; Accepted: 05 February 2020; Published: 10 February 2020

\section{Resumen}

\begin{abstract}
El trabajo de la mujer en el campo es de gran importancia porque contribuye a la economía de su pueblo y a de su familia procedente de zonas vulnerables, que requieren mayor atención de las diferentes instituciones para mejorar su calidad de vida. El objetivo de esta investigación es determinar la integración de la mano de obra de la mujer en la agricultura, a través de un cuestionario y preguntas semi estructuradas a mujeres dirigentes dedicadas al sector agrario y mujeres obreras que laboran en el campo procedentes de los distritos de Imperial y Quilmana. Como resultado se identificó el gran potencial de crecimiento que consiguen las mujeres, y su contribución a la seguridad alimentaria, mejoras en la economía. Por otro lado, estas mujeres se caracterizan por pertenecer a sectores vulnerables; por lo que su participación en la fuerza laboral implica mayor cuidado y delicadeza especialmente en las empresas agroexportadoras. En lo que respecta a la igualdad de género es similar en el trabajo al de los hombres en las actividades agrícolas, pero con menos ingresos en los salarios. Por tanto, las mujeres tienden a contribuir en la mejora económica de su canasta familiar rural, siendo capaces de demostrar un gran potencial en el desarrollo laboral, asumiendo retos frente a la pobreza y la desigualdad de oportunidades, ante un estado que emerge de una desconfianza e incumplimiento de las políticas públicas agrarias, que impiden el desarrollo profesional por carencia de recursos económicos en las zonas rurales del valle de Cañete, Región Lima, Perú.
\end{abstract}

Palabras clave: Integración, mujer, agricultura, economía.

\begin{abstract}
Women's work in the countryside is of great importance because it contributes to the economy of their people and their families from vulnerable areas, which require more attention from different institutions to improve their quality of life. The objective of this research is to determine the integration of the workforce of women in agriculture, through a questionnaire and semi-structured questions to women leaders dedicated to the agricultural sector and women workers who work in the field from the districts Imperial and Quilmana. As a result, the great growth potential of women and their contribution to food security, improvements in the economy were identified. On the other hand, these women are characterized by belonging to vulnerable sectors. Therefore, their participation in the labor force implies greater care and delicacy, especially in agro-export companies. With regard to gender equality, it is similar in work to that of men in agricultural activities, but with less income in wages. Therefore, women tend to contribute to the economic improvement of their rural family basket, being able to demonstrate great potential in labor development, taking on challenges in the face of poverty and inequality of opportunity, in the face of a state that emerges from mistrust and breach of agricultural public policies, which prevent
\end{abstract}




\section{Journal of Sciences and Engineering}

Vol. 4, $\mathrm{N}^{\circ} 1,2020$

Copyright @ 2020, CINCADER.

ISSN 2523-9503

DOI: https://doi.org/10.32829/sej.v4i1.126

professional development due to lack of economic resources in the rural areas of the Cañete Valley, Lima Region, Peru.

Keywords: Integration, women, agriculture, economy

\section{Introduction}

This research tries to demonstrate the contribution made by women in the field contributing to improve their family economy, as well as the community, due to the lack of jobs, in addition to the productive diversity that develops in the Cañete Valley. This situation allows women's work to be guaranteed in the agricultural sector, carrying out light and strong activities such as planting, cleaning weeds, fertilizing the land, harvesting. On the other hand, agro-exporting companies prioritize their activity in the harvest and in the selection of fruits. The identified problem lies in the lack of labor supply for women lacking higher education than existing in the area, so these women tend to go in search of work in agro-exporting companies where they carry out productive activities or field work private landowners, in order to get a paid job, one of the characteristics of these women is to be mothers who do not have other economic income, except for the activities they carry out through their personal effort, obtaining lower salaries than men, which generates inequalities. However, they are mostly from rural areas and marginal areas of low resources and in a state of vulnerability to the economic crisis they are going through. However, it is important to note that his work has an impact on active economic activity, which is being generated by the populations of women in a state of vulnerability in the Cañete Valley. Therefore, the potential for growth is framed in the participation of the workforce with gender equality, with public policies that allow generating a common good in society in general and especially the working women who are in vulnerable áreas.

Agriculture is considered to be one of the least paid jobs that currently exists in the country, in addition to being of little value for people and for the same State (Marin, 2017). Facts that are observed in the differentiation of women's salaries in comparison to the salaries assigned to men, the needs of women are limited in supporting the family basket to improve their income, they seek to get work activities in agricultural fields or from agro exporting companies. The incidence is observed in low-income households, assuming women work to support their families (Ramirez and Torres, 2014). However, faced with different disadvantages, women continue with family and agricultural work, empowering the directionality of their family nucleus. Thus, the feminization of the rural labor force refers to the increase in the presence of rural women in rural agricultural jobs, rural non-agricultural employment as employers, salaried or self-employed or unpaid family workers (Valenciano et al., 2017). It is corroborated that women's labor actions are carried out in the production or domestic fields, fulfilling a double labor function.

This social phenomenon is evidenced in the overload of responsibilities that women have, in family tasks based on social inequality, in discrimination and disadvantages that they experience in the labor market, manifesting themselves mainly in difficulties to insert themselves into labor; lower job opportunities, product of labor segregation; lower income, coupled with wage discrimination and inadequate valuation of occupations developed by women; and finally, greater informality, based on the representation of women in the informal economy and in jobs without social protection (Caamaño, 2010). The work of women, both paid and unpaid, becomes a fundamental key to the understanding of their enormous productive contribution in the construction of well-being or domestic well-being, in addition, of activities that cross the borders of the home (Diaz, 2017).

Currently, the situation of women in the labor market is a matter of great importance, if one takes into account that there are many who work or want to do so and their levels of response to labor can be equated like that of men (Agut and Salanova, 2014). This enables its easy incorporation 


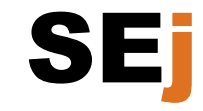

Vol. 4, $\mathrm{N}^{\circ} 1,2020$
Journal of Sciences and

Engineering

Copyright (C) 2020, CINCADER.

ISSN 2523-9503

DOI: https://doi.org/10.32829/sej.v4i1.126

into the labor world in search of a job in the productive activity as in agriculture, the main economic support of the Cañete Valley, complementing the jobs in the field. Therefore, it is raised as the main problem How is the integration of the workforce of women in agriculture in the Cañete Valley?, The specific problems being first How is the integration of women in agriculture, regarding to the potential for growth in the Cañete Valley?, Second How is the integration of women in agriculture, regarding the participation of women in the labor force in the Cañete Valley? And finally, how is the integration of women in agriculture, regarding gender equality in the Cañete Valley?

According to the Ministry of Development and Social Inclusion (MIDIS, 2017) it defines the scope of its competence, first to social development, in order to overcome poverty without inclusion with equity, second to social protection, mainly to vulnerable, at-risk populations and abandonment: which aims to improve the quality of life of the population, with access to opportunities, capacity building of both public, private institutions and society as a whole.

The Ministry of Agriculture and Irrigation (MINAGRI, 2016) highlights the gender approach, both for men and women in a balanced way, their participation, in order to close inequality gaps, for a correct decision making. However, within this the woman, fulfills various activities at home as in the management of agricultural production units. Demonstrating integrative capacity in various additional actions for the good of his family. Consequently, the national agricultural policy has as its main objective, to achieve the sustained increase in income and livelihoods of agricultural producers and producers.

\section{Theoretical framework}

\subsection{Women and economic growth}

Differentiated or inappropriate treatment manages to marginalize women, and therefore hinders their intervention and participation as a person of great potential and productive skills, which contributes to society and the development of the economy in a meritorious way (Lagarte, 2019). However, gender equality allows women to reach a seat, which with sacrifice managed to achieve the implementation of public policies, and therefore increase the number of women in the labor market, these being paid and managing to reduce wage gaps, but, nevertheless, obstacles arise in high-risk work, making it impossible to continue its activity (Dabla-Norris and Kochhar, 2019). This gender wage gap continues, and the jobs typically occupied by women, continue to be dismissed, consequently, poorly paid, with a labor market that is favored by the work of men and marginalizes women (Jakobsdóttir, 2019)

Women and rural employment in Peru, aims to identify the main characteristics of female rural employment. The female population over 18, working in rural areas of Peru, highlights those women in rural areas dedicated to agriculture, because they have developed various types of non-agricultural activities as a work alternative that has allowed them to contribute economically in the Development of their families. The research identified a gender difference, women, although to a lesser extent, have the same job opportunities as men in the rural areas analyzed; education and having minor children is no longer an impediment to self-generating their own source of work and in order to get ahead it has not been necessary to migrate to the city. However, it was also identified that the quality of employment is still precarious, temporary and with very variable economic income that has forced women to work in many cases for more than eight hours and also perform more than one work activity (Cornejo et al., 2016).

Labor discrimination and its effect on working women of the Departmental Head Municipality of Huehuetenango, aims to establish the existence of labor discrimination and its effect on working women of the Municipality, applied to 25 women, the results show according to age: $36 \%$ of working women are between 30 and 39 years old and have not been discriminated against, $68 \%$ 


\section{SE \\ Vol. 4, $\mathrm{N}^{\circ}$ 1, 2020 \\ Journal of Sciences and Engineering}

Copyright (c) 2020, CINCADER.

ISSN 2523-9503

DOI: https://doi.org/10.32829/sej.v4i1.126

\section{CINCADER}

Centre of Research and Training for

Regional Development

Online at www.journals.cincader.org

of working women contribute to the home, concludes that the main cause of labor discrimination according to $52 \%$ of women interviewed It is because they do not know what their labor rights and responsibilities are, due to lack of knowledge and little information (López, 2014).

The participation of women in productive activities and community organization in the peasant community of Matachico-Lloccllapampa-Jauja, achieve their participation in communal organizations, actively through the board of directors, assemblies and communal tasks (Ramirez and Torres, 2014).

The situation of women in the Cañete Valley is not alien to this reality, where the workforce of women is highly valued in various productive activities in the countryside with a greater incidence in plantings, harvesting of fruit trees, classification among other agricultural activities, which inculcate in improving their living conditions, work, family and community development, as shown in figure 1, after vine leaves, for the beginning of fruiting in the agricultural fields of the Center La Esmeralda Village, San Vicente - Cañete.

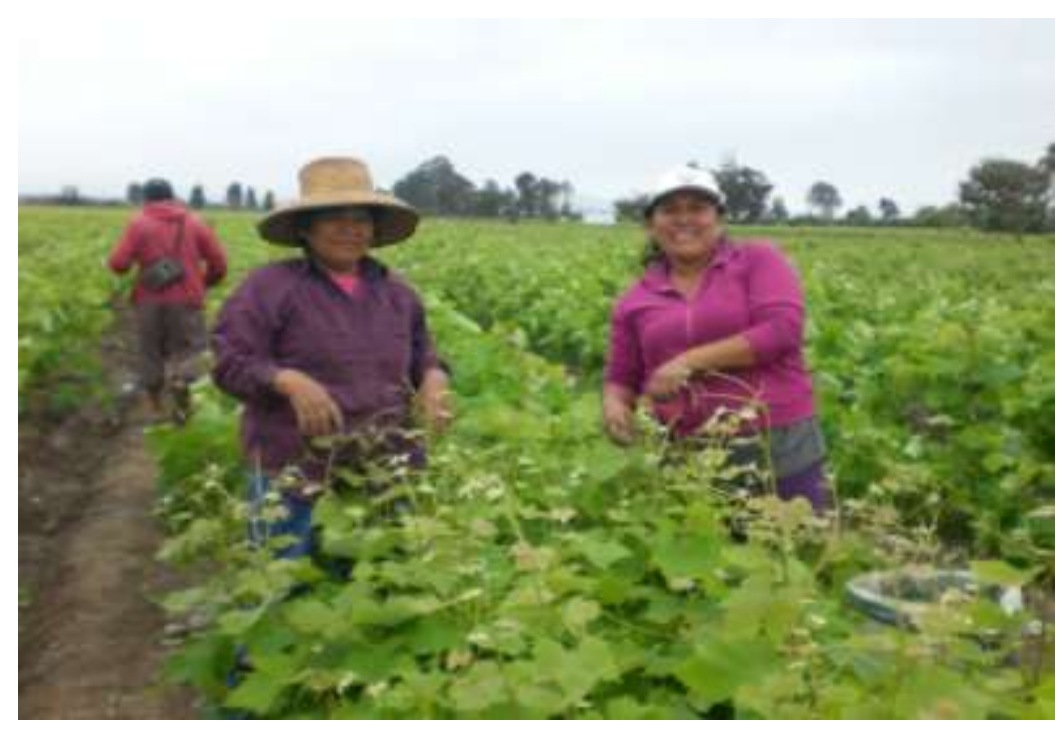

Figure 1. Outbreak of vine leaves of women in the field

\subsection{Growth potential}

The potential growth of an economy, understood as the materialization of the employment of productive resources" (Aravena, 2010).

The intensification of growth with the women's workforce is achieving the vertiginous advance of an action generated by the need to improve their economy against the increase in the basic family basket, as shown in Figure 2, where work The field is continuous and permanent in agro-export companies, the effect of agricultural campaigns that provide great ease to women in rural areas of the Cañete Valley, who do not have a professional career, being these mothers with scarce economic resources and vulnerable áreas. 


\section{SE \\ Vol. 4, $\mathrm{N}^{\circ}$ 1, 2020 \\ Journal of Sciences and Engineering}

Copyright (c) 2020, CINCADER.

ISSN 2523-9503

DOI: https://doi.org/10.32829/sej.v4i1.126
Figura 2. Woman in process of mooring in Holantao

Figura 2. Woman in process of mooring in Holantao

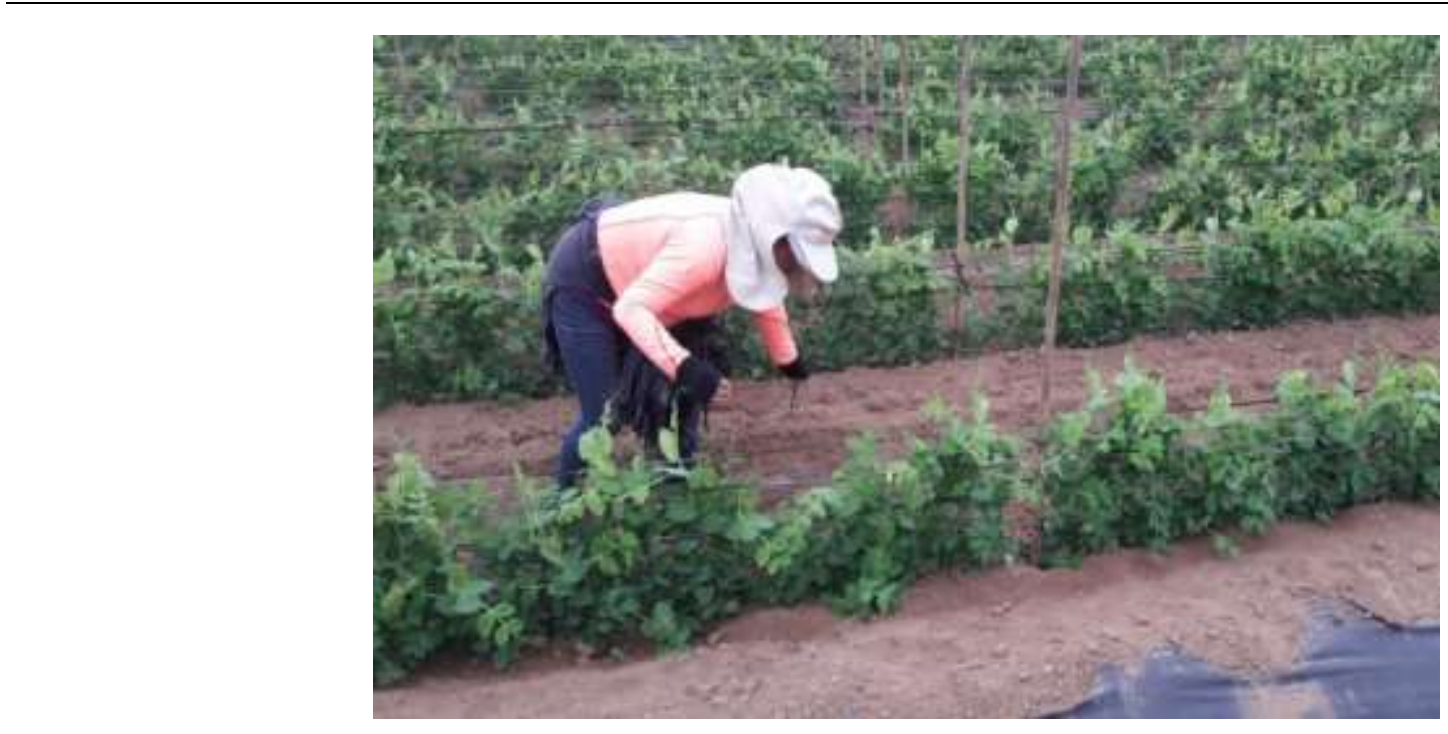

Centre of Research and Training for

Regional Development

Online at www.journals.cincader.org

\subsection{Participation in the workforce}

"The importance of promoting women's participation in the world economy as a development agent not only for their family, but also for their community, in the most vulnerable sectors in situations of poverty and extreme poverty" (MIMP, 2014).

The Lima region, specifically the province of Cañete, shows the development of women in the labor force, increasing economically active production (EAP), and therefore the sustainability of economically vulnerable areas, as a symptom of survival through the countryside. Empowering their labor actions, which migrate from company to company, according to productive heading or seasonal agricultural campaigns.

\subsection{Gender equality}

"They are the economic, social, political and cultural attributes and opportunities associated with being a man or a woman" (FAO, 2012). The gender approach in the productive activity of the Cañete Valley is synonymous with entrepreneurship, courage, courage, discipline and effort to balance the work balance with equality. That encourages their actions as a responsible mother and woman in their home and adverse circumstances of the national economy, which the responsible entities do not focus on their actions. Importance of gender equality in agriculture is of vital importance to achieve agricultural development and achieve the millennium development goals (FAO, 2012). Meanwhile, women have been evolving through cultural events, gradually incorporating into the agricultural work in their area, they managed to change their family lifestyles, so they put aside the saying that women are from home and Men can go to work in agriculture (Marín, 2017). And gender equality does not symbolize that men and women are or should be similar, but that both enjoy the same benefits of life (Martínez and Baeza, 2017). Therefore, empowering women is of great importance for rural development, sustainable agriculture, food security and nutrition improvement (Ramos, 2018). Another important aspect is that women who work in the rural economy are discriminated against for different reasons, with gender being the main cause of inequality, ethnic or social origin and their religion (ILO, 2017) 


\section{SE \\ Vol. 4, $\mathrm{N}^{\circ}$ 1, 2020 \\ Journal of Sciences and \\ Engineering}

Copyright (c) 2020, CINCADER.

ISSN 2523-9503

DOI: https://doi.org/10.32829/sej.v4i1.126

\section{Results}

Below is the semantic network of the research conducted in atlas ti.

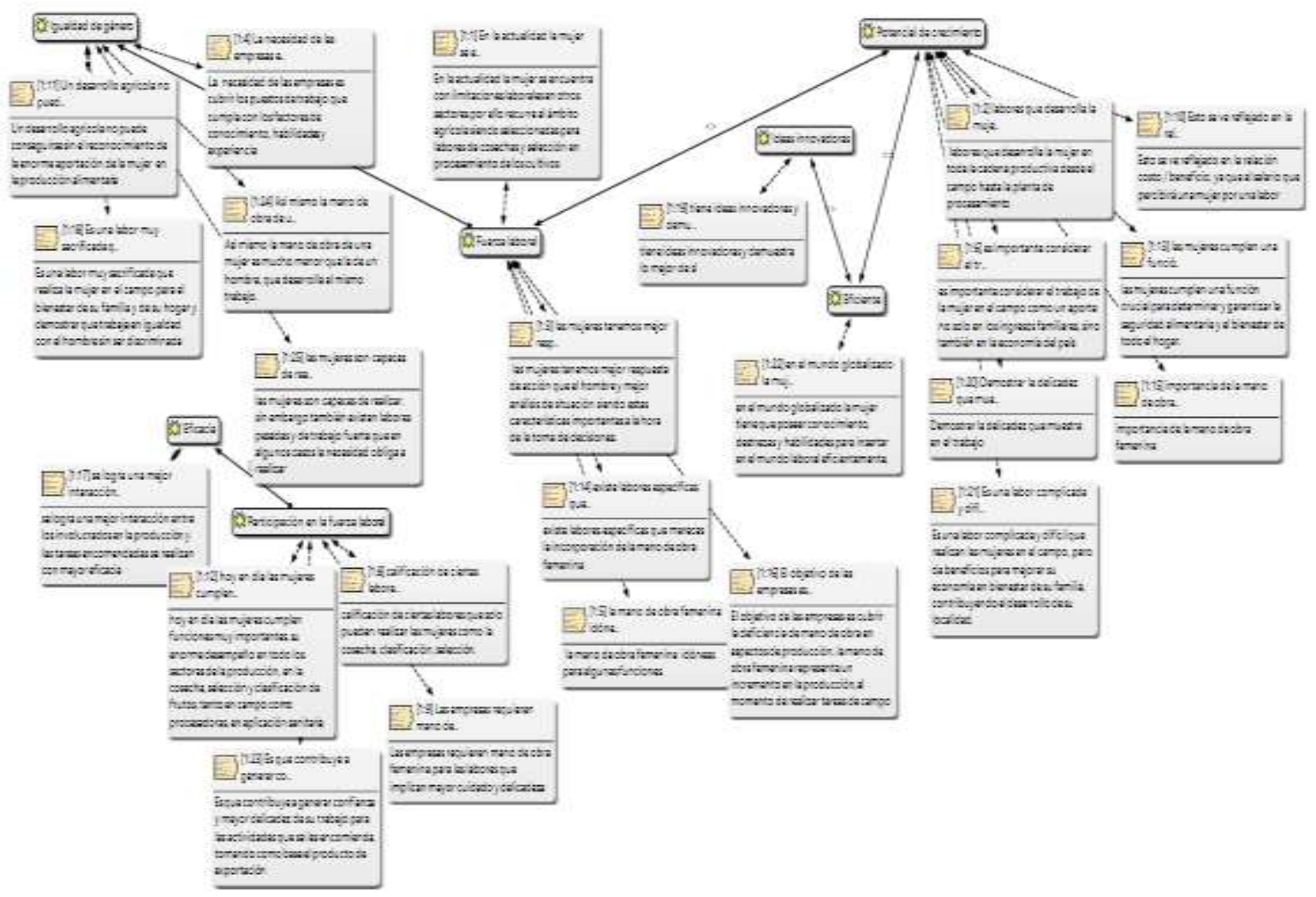

Figure 3. Semantic Research Network

\subsection{Growth potential}

The integration of women into the countryside in the Cañete Valley is reflected with a great potential for job growth that they develop throughout the productive chain from the field to the processing plant. However, the importance of their work not only derives to improve their family income but also contributes to the economy of the country. Women carry out complicated and difficult tasks in the field in order to guarantee the well-being of their family and therefore their personal growth, maintaining their economic independence, and availability to generate their own expenses, many of them being single mothers, from vulnerable places, achieving the economic benefit for their children and their implementation in education, which is evidenced in the cost / benefit that leads to continue providing their work in the different agricultural companies, in which they fulfill crucial functions to determine food security, well-being from the home and society through labor in the field. The contributions of innovative ideas and efficient work allow the workforce of companies or agricultural fields to be guaranteed.

\subsection{Participation in the workforce}

Women manage to join the labor force of the field, through tasks that are assigned allowing greater efficiency, their work being considered productive, dedicated, thorough, and therefore efficient in the performance of the assigned functions in all productive sectors, which are It begins with the production, sowing, harvesting, selection and classification of fruits, both in the field and in the processing plants, which generates confidence for the delicate work in the entrusted activities, highlighting that the final product allows export. Consequently, companies require 


\section{SE \\ Vol. 4, $\mathrm{N}^{\circ}$ 1, 2020 \\ Journal of Sciences and \\ Engineering}

Copyright (C) 2020, CINCADER.

ISSN 2523-9503

DOI: https://doi.org/10.32829/sej.v4i1.126

female labor for tasks that involve greater care and delicacy because they report better results, with ages that are distinguished in Table 1 and Figure 4.

Table 1. Age of women working in the field

\begin{tabular}{cccccc|c}
\hline & & Frequency & $\%$ & Valid $(\%)$ & Accumulate (\%) \\
\hline Valid & $<=20$ & 9 & 16,4 & 16,4 & 16,4 \\
\cline { 2 - 6 } & $21-30$ & 23 & 41,8 & 41,8 & 58,2 \\
\cline { 2 - 6 } & $31-40$ & 12 & 21,8 & 21,8 & 80,0 \\
\cline { 2 - 6 } & $41-50$ & 8 & 14,5 & 14,5 & 94,5 \\
\cline { 2 - 6 } & $51+$ & 3 & 5,5 & 5,5 & 100,0 \\
\hline & Total & 55 & 100,0 & 100,0 & \\
\hline
\end{tabular}

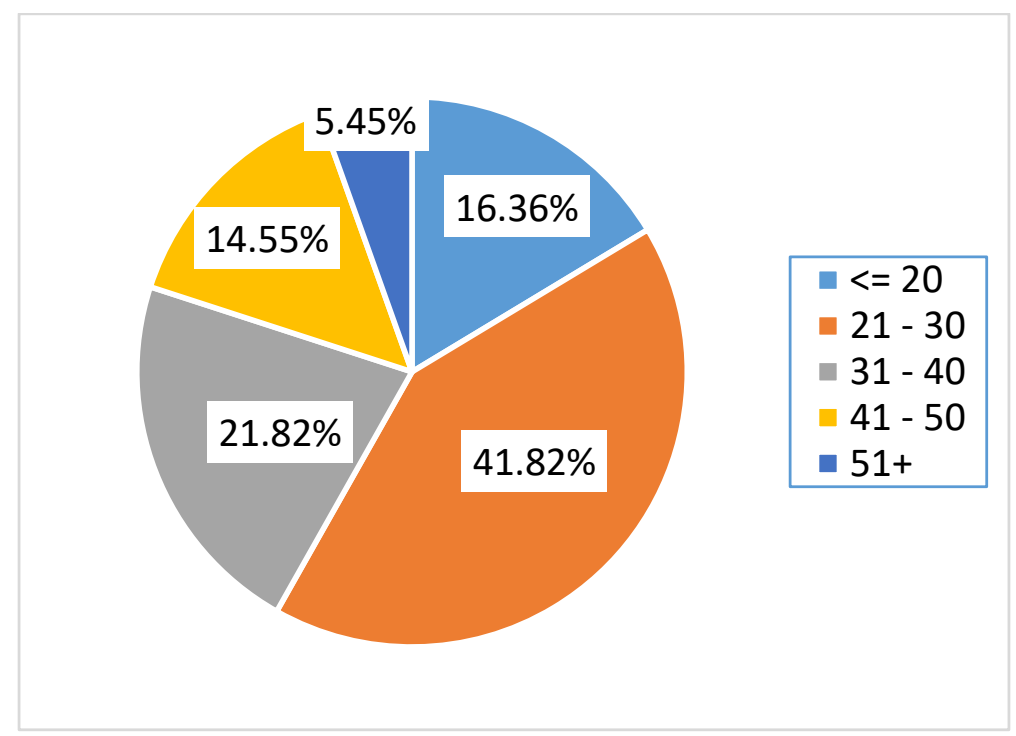

Figure 4: Employability representation by age of women working

Of the $100 \%$ of women surveyed, the highest employability in the field are those women that range from 21 to 30 years, and represent $41.82 \%$, followed by $21.82 \%$ between 31 and 40 years old.

\subsection{Gender equality}

Agricultural development cannot be achieved without the recognition of the enormous contribution of women in food production, sacrificed work generated in the field of agricultural products for the well-being of their family, their home and demonstrate that they work in equality with men without be discriminated against Effect of a functional commitment with companies that need to fill the jobs provided they meet knowledge, skills and experience otherwise they are trained for different sectors that the agricultural company has, however, the workforce of women is considered lower than men being the same work they do, in addition, to carry out heavy work activities and hard work, which in some cases the need forces to perform. Therefore, the labor force in the field is the same for both genders, starting their activities from seven in the morning until three in the afternoon, which corresponds to one day. Then they move to their homes by means of transport. 


\section{Journal of Sciences and Engineering}

Vol. 4, $\mathrm{N}^{\circ} 1,2020$

Copyright @ 2020, CINCADER.

ISSN 2523-9503

DOI: https://doi.org/10.32829/sej.v4i1.126

\section{Conclusions}

Women have great potential for labor development capable of taking on challenges in the face of poverty and inequality of opportunities, in the face of a state that emerges distrust and noncompliance with agricultural public policies, preventing professional development in women due to lack of economic resources in rural zones.

The incorporation of women in the agricultural field is recognized for their skills and for their participation in the workforce, being welcomed by the care and delicacy of their crop work, contributing to food security in the Cañete Valley, achieving more easily those women whose ages range from 21 to 30 years and their employability decreases at an older age.

Gender equality based on opportunities develops great interest in the agricultural field through balanced work between men and women, but with low wages in women than in men.

\section{References}

Agut S. y Salanova M., 2014. "Mujeres y trabajo: un reto para la instigación psicosocial," Revisa de Psicología Social,

Aravena C., 2010. Estimación de crecimiento potencial en América Latina, Santiago de Chile: CEPAL,

Caamaño Rojo E., 2010. Mujer y trabajo: origen y ocaso del modelo del padre proveedor y la madre cuidadora, Revista de derecho de la Pontificia Universidad Católica de Valparaíso.

Cornejo Corrales C. A., De la Cruz García L., Farfán Vignolo V. D. P. y Sandoval Soto J. G., 2016. Mujer y empleo rural en el Perú, Lima.

Dabla-Norris E. y Kochhar K., 2019. Cerrar la brecha de género, Las mujeres y el crecimiento económico,

Díaz Muñoz J. G., 2017. Mujer, trabajo y familia. Una perspectiva de género desde América Latina, Géneros Hiatita Press, vol. 6, n 3, p. 25.

FAO, 2012, Agricultura y desarrollo rural.

Jakobsdóttir K., 2019, Construir una economía inclusiva.

Lagarte C., 2019. Un imperativo mundial.

López Monjaras N. M., 2014. Discriminación laboral y su efecto en las mujeres trabajadoras de la Municipalidad Cabecera Departamental de Huehuetenango, p. 102,

Marín Delgado H. D., La mujer agricultora: cambio de percepción y tendencia cultural, 2 do. Congreso Latinoamericano de gestión cultural, 18,19 y 20 octubre 2017.

MIDIS, D. S. MIDIS, “Ley 29792, EI Peruano, 2011.

MIMP, 2014. Participación de la mujer en actividades productivas y empresariales, Lima: MIMP.

MINAGRI, 2016. Decreto Supremo que aprueban la política nacional agraria, El Peruano, p. 16,

OIT, 2017. "Fomento de la autonomía de la mujer en la economía rural", p. 6,

Ramírez Chocce V. J. y Torres Hinostroza D. E., 2017. La participación de la mujer en actividades productivas y organización comunal en la comunidad campesina de MatachicoLloccllapampa-Jauja, Huancayo, 2014. Martínez Montero I. y Baeza Leiva M., Enfoque de género en el papel de la mujer rural en la agricultura cubana, Prolegómenos - Derechos y valores, vol. $20, \mathrm{n} \cong 39$, p. 9 ,

Ramos G., 2018. "Las mujeres de las comunidades rurales siguen siendo uno de los grupos más marginados", IICA, p. 89, 


\section{SE}

Vol. 4, $\mathbf{N}^{\circ} 1,2020$

Copyright (c) 2020, CINCADER.

ISSN 2523-9503

Journal of Sciences and

Engineering

DOI: https://doi.org/10.32829/sej.v4i1.126

\section{GINGADER}

Centre of Research and Training for

Regional Development

Online at www.journals.cincader.org

Valenciano J. d. P., Capobianco Urdiales M. y Uribe Toril J., 2017. Vulnerabilidad laboral de la mujer rural Latino Americana, Revista de Ciencias Sociales y Humanidades, vol. 26, p. 19, Julio-diciembre 